\title{
Social Safety Nets and Poverty in Pakistan (A Case Study of BISP in Tehsil Mankera District Bhakkar)
}

\author{
Syed M. Muddassir Abbas Naqvii, ${ }^{1,}$, Hazoor Muhammad Sabir ${ }^{1}$, Anisa Shamim ${ }^{1}$, Muhammad Tariq ${ }^{2}$ \\ ${ }^{1}$ Department of Economics, G.C University, Faisalabad, Pakistan \\ ${ }^{2}$ Ayub Agricultural research institute, Faisalabad Pakistan \\ *Corresponding author: nmuddassirqau@yahoo.com
}

Received January 23, 2014; Revised February 14, 2014; Accepted March 04, 2014

\begin{abstract}
Benazir Income Support Program (BISP) is an important safety net among the poverty reduction strategies. Although, cash transfer of PKR1000 per month cannot change the whole social status of the people in this era of rising inflation and frequently increasing oil prices, yet it provides some relief for daily household expenditures (especially food, education and health expenditures) for the poorest of the poor families. Primary data of 156 households ( $3.44 \%$ of the beneficiaries' households, which is equivalent to $0.58 \%$ of the total population of the Tehsil), was collected from all the 7 union councils of Tehsil Mankera, District Bhakkar through proportionate sampling. The data was analyzed through SPSS for frequency distribution and Chow's test was applied to check the structural stability in the social status of the beneficiaries before and after the program. The results showed that there was a structural stability in the life of the BISP beneficiaries after the program was started and their expenditure and thus consumption patterns had also increased. This improvement in consumption pattern means progress in the welfare of the beneficiary population which shows there is a trend towards reducing poverty.
\end{abstract}

Keywords: BISP, poverty, welfare of the people, trend in reduction of poverty

Cite This Article: Syed M. Muddassir Abbas Naqvi, Hazoor Muhammad Sabir, Anisa Shamim, and Muhammad Tariq, "Social Safety Nets and Poverty in Pakistan (A Case Study of BISP in Tehsil Mankera District Bhakkar).” Journal of Finance and Economics, vol. 2, no. 2 (2014): 44-49. doi: 10.12691/jfe-2-2-1.

\section{Introduction}

Poverty is a phenomenon which existed for centuries, rather since the very existence of the human beings. Absolute poverty means one who lacks basic human needs which commonly includes clean and fresh water, nutrition, health care, education, clothing and shelter. Around 1.29 billion persons or $22 \%$ of the populace of the developing world were living in absolute poverty.

There are so many causes of poverty in Pakistan which include bad administration, higher population growth, high cost of living, increasing joblessness, insufficient schooling, atmosphere deprivation, imbalanced allocation of capital especially agricultural land etc [10].

To overcome these problems various governments developed poverty alleviation programs as a consequence of rural development or employment creation. These were, e.g., rural development programs such as Village Aid in 1950, Rural Works Program, People Works Programs, Social Action Program and other similar programs [8]. Many social safety nets measures have been tried and are still being tried in Pakistan for poverty alleviation. Safety nets programs provide a safeguard to households against two injurious effects in welfare, one of them is chronic poverty due to chronic incapacity to work and earn, and the other is a decline in this capacity from an important situation that afford minimum livelihood for survival with few strings [4]. In Pakistan, recently two types of social safety nets are working, one of them is budgetary and others are non-budgetary social safety nets. The budgetary social safety nets are Pakistan Poverty Alleviation Fund(PPAF), Benazir Income Support Program (BISP), People Works Program-1\&11 (PWP-1\&11). The nonbudgetary social safety nets include Pakistan Bait-ul-Mall, Zakat, Employees Old Age Benefits Institutions (EOBI), Workers Welfare Fund (WWF) and Microfinance Initiatives [11].

Out of all these safety net programs this paper attempted to primarily focus on only one social safety net (BISP). The BISP was chosen for detailed study to measure its impact on the overall poverty reduction in the country because of its significance as being the largest countrywide social safety net program ever introduced in Pakistan specially targeting women. By the time of study it was covering 3.9 million women starting with a budget of Rs.34 billion in the year 2008-09 that increased to Rs.75 billion in the year 2013-14.

The BISP was started in July 2008, as a major social safety net program. The purpose of this countrywide program was to give income support and other benefits to the poorest families to mitigate harmful effects of inflation and food crises. Its long standing objective is to set up a countrywide safety net program, distinct by effectual and clear targeting and distribution mechanisms. The President of Pakistan issued an ordinance in April 2009 to provide self-governing status to BISP and to ensure its continuity. 
The Ordinance has been accepted by the Pakistan Parliament into an Act i.e. The Benazir Income Support Program Act 2010.

The program started by giving unconditional cash transfers of PKR 1000 per month to entitled families. The Government wants to increase social support spending significantly. The BISP was allocated PKR 34 billion in financial year 2008-09, 40 billion in 2009-10, and 50 billion in 2010-11. The most recent budget for fiscal year 2013-14 has allocated PKR 75.0 billion and amount of monthly support has been increased from PKR 1000 to PKR 1200 per month, a 20\% increase.

The eligibility criteria to become a BISP beneficiary include a monthly income of less than PKR 6000, no family member in government service, ownership of no or less than three acres of agricultural land or up to three Marlas residential property, possession of national identity card, should not be a beneficiary of any other program, should not hold an account with a foreign bank, should not possess a passport or an overseas Pakistani identity card [13].

The BISP has further extended to include special initiatives such as Waseela-e-Haq program (empowering women by provision of small loans), Waseela-e-Rozgar (offering members of entitled families up to 1 year of professional training) and Waseela-e-Sehat program (providing financial assistance especially for obtaining basic health care) [1].

In the start, payment to the beneficiaries was made possible through Pakistan Post Office. Now, BISP is using alternative payment mechanisms, which include Benazir Debit Card, Smart Card and Mobile Banking to efficiently make payments of the cash grants to its beneficiaries [11].

The objectives of the study included 1) to assess the impact of BISP on poverty in Tehsil Mankera, district Bhakkar 2) to estimate the social status and consumption of the beneficiaries of BISP before and after the program commencement in the said area and to illustrate deductions from the discussion and make suggestions.

This article is written in five parts. Section 1 gives introduction, the section 2, is on a review of literature conducted in the field of poverty and social safety nets. Section 3 gives methodology. The fourth section deals with results and discussion and section five contains suggestions and policy recommendations.

\section{Literature Review}

Case and Deaton [3] conducted a study on Large Cash Transfers to the Elderly in South Africa. The data was collected from the national household survey of South Africa conducted in cooperation with the World Bank and the South African Development Research Unit (SALDRU) at the University of Cape Town. The size of the sample was 9000 households which were randomly selected from all races and areas, including the so-called independent households. The results showed that pension income is spent in much the same way as other income and that a rand is a rand, in spite of its source.

Ravallion et, al. [16] carried out a study on testing a social safety net. They used the methodology of PROT and PROM tests for motivation. The results showed that there was an increase in consumption over this period. The gains in social incomes were that half of an increase in cash benefits received was passed on to current consumption. The decrease in temporary poverty was due in large part to the increase in mean cash benefits rather than improved targeting.

Hicks and Wodon [6] conducted a study on economic shocks, safety nets and fiscal constraints: social protection for the poor in Latin America. The purpose of the study was to focus on publically funded or mandated safety nets functioning as risk-copying mechanisms. The results showed that because of fiscal constraints during crises, social spending is often pro-cyclical when ideally it should be counter-cyclical and social protection spending itself does not appear to be protected.

Schultz [17] conducted a study on School Subsidies for the poor: Evaluating the Mexican Progresa Poverty Program. The results showed that level of enrollment rates of comparably poor children in Progresa localities (treatment) were higher than in non-Progresa localities (control) in the three survey rounds collected after September 1998 when the Progresa program began offering educational grants to poor mothers whose children were enrolled in school in grades 3 through 9.

Nino and Dorosh [15] conducted a study on In-Kind transfers and household food consumption: Implications for the targeted food programs in Bangladesh. They used the methodology of propensity score matching and Engel function. The results showed that total marginal propensity to consume (MPC) for wheat is, on average, 0.33, ranging from essentially zero for Food for Work (a program with large transfers) to 0.51 for Food for Education.

Duflo [5] conducted a study on Grandmothers and Grand-daughters: Old-age Pensions and Intra household Allocation in South Africa. The methodology used was Ordinary Least Square (OLS) and two stage least square. The results showed that pensions received by women had a large impact on the anthropometric status (weight for height and weight for age) of girls but little effect on that of boys.

Walle [18] conducted a study on Testing Vietnam's Public safety Net. The marginal propensity to consume out of social income (PCSI) was applied on this data. The results showed that the government's safety net programs made only insignificant influence to that positive outcome. There were both losers and gainers during that period. These programs did not achieve a genuine safety net role in protecting those who faced falling living standards during the period.

Jalan and Ravallion [9] conducted a study on Estimating the Benefit incidence of an Antipoverty Program by Propensity Score Matching. The results showed that mean direct gain to the participant was found to be about half the gross wage. One half of the beneficiaries were in the poorest deciles and $80 \%$ were in the poorest quintile. Moreover, program participants were more likely to be poor than nonparticipants by a variety of both objective and subjective indicators. The participants tended to be less well educated, lived in poorer neighborhoods and tended to be members of neighborhood associations and political parties.

Imai [7] conducted a study on The Employment Guarantee Scheme as a Social Safety Net-Poverty Dynamics and Poverty Alleviation. Cox Proportional 
Hazard model was used to estimate the likelihood of entering or exiting poverty by various covariates. The results showed that Employment Guarantee Scheme has significant promotional and defensive roles irrespective of the choice of income poverty lines.

Booysen [2] conducted a study on Social grants as a safety net for HIV/AIDS affected households in South Africa. The purpose of the study was to examine the role of social grants in extenuating the socio-economic impact of HIV/AIDS in South Africa. The results showed that affected households were more dependent on income from social grants as compared with households that had never experienced humanity.

\section{Methodology}

Mankera tehsil of district Bhakkar was chosen for the purpose of this study because it is the most backward but, in terms of area, the largest tehsil of Punjab, Pakistan [10]. In this research study proportionate sampling was used. The target was to collect the data of 150 BISP beneficiaries proportionally from all union councils relative to the tehsil total of 4538 beneficiaries. But as against the set target of 150 , the data were actually collected for 156 beneficiaries.

In this study Monthly expenditures of the household was taken as a dependent variable as a proxy for consumption while number of family members, gender, work status, and education of household head, land ownership, disabled person, unexpected shocks, loan obtained, total small (goats and sheep) and large animals (cows and buffalos) were used as independent variables.

The reason for taking disabled person as an independent variable was to check its impact on household expenditures. According to Assistant Complaint Officer, BISP, Tehsil Mankera, District Bhakkar, BISP had its own criteria of assigning poverty score and the household who had a disabled person were given 5 additional score as compared to those households without disabled person. Similarly, unexpected shocks included damage of a household katcha room, wall, death of a small or a large animal during the last 3 years after the program started to see if it had affected household expenditures or not.

The Chow's test was used for the structural stability. It was founded by Chow in 1960. The test consists of breaking the sample into two structures (or more according to the case), estimating the equation for each of them, and then comparing the SSR from the separate equations with that of the entire sample.

In order to apply the Chow's test the following steps were followed:

Step 1: Calculated the basic regression equation:

$$
Y_{t}=\beta_{1}+\beta_{2} X_{2 t}+\mu_{t}
$$

For three different sets:

a. The whole sample (n); (b) The period before the program $\left(n_{1}\right)$, and (c) The period after the program $\left(n_{2}\right)$. Step 2: found the SSR for each of the above three subsets and labeled them as $\mathrm{SSR}_{\mathrm{n}}, \mathrm{SSR}_{\mathrm{n} 1}$, and SSRn2 respectively. Step 3: Calculated the following F statistic.

$$
F=\frac{\left(S S R_{n}-\left(S S R_{n 1}+S S R_{n 2}\right)\right) / k}{\left(S S R_{n 1}+S S R_{n 2}\right) /\left(n_{1}+n_{2}+2 k\right)}
$$

Where $\mathrm{k}$ is the number of parameters estimated in the equation of step 1 (for this case $k=2$ ).

Step 4: Calculated the F statistic obtained above with the critical $F_{(k n 1+n 2+2 k)}$ for the required significance level.

If F-statistics $>$ F-critical then we reject the hypothesis $\mathrm{H}_{0}$ that the parameters are stable for the entire data set and conclude that there is proof of structural instability.

\section{Results}

\subsection{Impact of the BISP}

All the 156 respondents (100\%) were unemployed before and after the start of the BISP, which was also the part of eligibility of becoming BISP beneficiary.

Before the start of the program $91.1 \%$ of the household heads were unemployed while only $8.9 \%$ were employed. After the program initiation, $80.9 \%$ of household heads were unemployed while $19.1 \%$ were employed so the percentage of employed workers had increased.

$57.9 \%$ of the beneficiaries had no goat or sheep or only $1,29.9 \%$ had 2 to 4 small animals, $11.6 \%$ had 5 to 10 and $0.6 \%$ had even 20 small animals. After the BISP program started, this percentage had increased i.e. $67.4 \%$ had 2 to 4 , $32.0 \% 1$ had 5 to 10 goats or sheep.

Before program initiation, $33.3 \%$ of the beneficiaries had no large animal, $46.2 \%$ had $1,20.5 \%$ had 2 , while after the program initiation this situation remained the same because large animals being costly, an amount of PKR 1000 could not enable purchasing a large animal.

Before start of the program $99.4 \%$ of the respondents had none while only $0.6 \%$ had a motorcycle. After the program, $97.4 \%$ had none while $2.6 \%$ had a motorcycle. Percentage of households having motorcycle increased from $0.6 \%$ to $2.6 \%$. Before the start of the BISP program, $99.4 \%$ had none while $0.6 \%$ had a refrigerator. The percentage of beneficiaries having refrigerator increased from $0.6 \%$ to $1.3 \%$ only.

Before the start of the program, $87.2 \%$ of the beneficiaries' households had none and only $12.2 \%$ had a TV while after the program $78.8 \%$ had none while $21.2 \%$ had a TV. One can infer that now- a- days even rural people prefer to have a television if they can afford. Therefore, number of beneficiaries having a TV increased from $12.2 \%$ to $21.2 \%$. Before the start of the BISP program, $100 \%$ of the respondents had no washing machine but after the program there was a slight improvement and $0.6 \%$ had a washing machine. Before the start of the program, $46.8 \%$ had obtained loans while $53.2 \%$ had no loans. After the program, 59.6\% had obtained loans while $40.4 \%$ had no loans and thus number of households receiving loans increased, which indicates increase in their creditworthiness.

Before the start of the program, minimum expenditures were PKR 2000 and maximum were PKR 22000 while the mean was PKR 8439.10 per month. After the BISP program, minimum expenditures were PKR 3000 and maximum were PKR 32000 while the mean was PKR 12044.87 (table 4.1). So, after the program expenditures increased from PKR 8439.10 to PKR 12044.87, i.e. an increase of PKR 3605.77 in monthly expenditures of household. Increase in expenditures means consumption of the households also increased [12]. 
Table 4.1. Mean Expenditures of the households before and after the program

\begin{tabular}{|c|c|c|c|c|c|c|}
\hline Monthly Expenditures of households & \multicolumn{3}{|c|}{ Before } & \multicolumn{2}{|c|}{ After } \\
\hline & Min & Max & Mean & Min & Max & Mean \\
\hline 156 households & 2000.00 & 22000.00 & 8439.1026 & 3000.00 & 32000.00 & 12044.8718 \\
\hline
\end{tabular}

Consumption can be used as a proxy for the poverty. All the above descriptive statistics including animals, assets, land ownership etc. shows that after the initiation of the program and receiving monthly income support, the consumption had improved. When the consumption has improved it means welfare of the people has improved and when the welfare of people improved, it means poverty was reducing.

\subsection{Testing for Structural Stability}

To check whether the social status of the BISP beneficiaries before and after the program improved or not, chow's test was used.

The results of the chow's test were calculated as follows:

1. First of all, before program the regression was estimated through OLS.

$Y$ (Monthly expenditures of household)

$=\beta_{o}+\beta_{1}$ (No of family members $)$

$+\beta_{2}$ (Gender of household head)

$+\beta_{3}\left(\begin{array}{l}\text { Work status of household head } \\ \text { before program }\end{array}\right)$

$+\beta_{4}($ Education of household head $)$

$+\beta_{5}($ Land ownership $)+\beta_{6}($ Disabled person $)$

$+\beta_{7}$ (Unexpected shocks)

$+\beta_{8}$ (Loan obtained before program)

$+\beta_{9}$ (Total small animals before program)

$+\beta_{10}($ Total large animals before program $)+\mu$

After the regression, residual sum of square were estimated from ANOVA.

RSS=Residual Sum of Squares

RSS $=13.34$ (before program)

2. In the second step, after program regression was estimated through OLS.

$Y$ (Monthly expenditures of household)

$=\beta_{o}+\beta_{1}$ (No of family members $)$

$+\beta_{2}$ (Gender of household head)

$+\beta_{3}$ (Work status of household head after program)

$\beta_{4}$ (Education of household head)

$+\beta_{5}($ Land ownership $)+\beta_{6}($ Disabled person $)$

$+\beta_{7}($ Unexpected shocks $)+\beta_{8}\left(\begin{array}{l}\text { Loan obtained } \\ \text { after program }\end{array}\right)$

$+\beta_{9}$ (Total small animals after program)

$+\beta_{10}$ (Total large animals after program $)+\mu$

As in the first step residual sum of squares were estimated from ANOVA.

RSS $=18.93$ (after program)
3. In the third step, regression was estimated combined through OLS (i-e before and after the program).

$Y$ (Monthly expenditures of household)

$=\beta_{O}+\beta_{1}$ (No of family members)

$+\beta_{2}\left(\begin{array}{l}\text { Gender of } \\ \text { household head }\end{array}\right)+\beta_{3}\left(\begin{array}{l}\text { Work status of } \\ \text { household head }\end{array}\right)$

$+\beta_{4}\left(\begin{array}{l}\text { Education of } \\ \text { household head }\end{array}\right)+\beta_{5}($ Land ownership $)$

$+\beta_{6}($ Disabled person $)+\beta_{7}$ (Unexpected shocks)

$+\beta_{8}($ Loan obtained $)+\beta_{9}($ Total small animals $)$

$+\beta_{10}($ Total large animals $)+\mu$

Residual sum of squares were estimated as before and after.

RSS $=37.52$ (combine)

The formula for the F-test is:

$$
F=\frac{R S S_{c}-\left(R S S_{b}+R S S_{a}\right) / k}{R S S_{b}+R S S_{a} / n-2 k}
$$

Where

$\mathrm{RSS}_{\mathrm{C}}=$ Residual Sum of Square (combine)

$\mathrm{RSS}_{\mathrm{b}}=$ Residual Sum of Square (before)

$\mathrm{RSS}_{\mathrm{a}}=$ Residual Sum of Square (after)

$\mathrm{k}=$ Number of parameters

$\mathrm{n}=$ Number of observations (total sample including before and combine)

$$
\begin{gathered}
F=\frac{37.52-(13.34+18.93) / 11}{\frac{13.34+18.93}{312-2(11)}} \\
F=\frac{\frac{37.52-32.27}{11}}{\frac{32.27}{290}} \\
F=\frac{0.477}{0.111} \\
F(11,290)=4.29
\end{gathered}
$$

$H_{0}$ : null hypothesis(there is no structural break)

$H_{1}$ : alternative hypothesis (there is a structural break)

Critical value of $F(11,290)=1.94$ at $5 \%$ level

Critical value of $F(11,290)=2.51$ at $1 \%$ level

$\mathrm{F}_{\text {cal }}>\mathrm{F}_{\text {critical }}$

4.29> 1.94 and 2.51

So, $\mathrm{H}_{0}$ is rejected and $\mathrm{H}_{1}$ is accepted.

This means there is a structural break in the social status of the BISP beneficiaries before and after the program. The BISP program is, thus, effective. In order to find out how this structural break occurred, it is discussed 
through the values of coefficients before and after the

program (ref. Table 4.2).

Table 4.2. Comparative Summary of Regression Analysis

\begin{tabular}{|c|c|c|c|c|c|c|c|c|}
\hline & \multicolumn{4}{|c|}{ Before BISP Initiation } & \multicolumn{4}{|c|}{ After BISP Initiation } \\
\hline Variable & Si. & Sig. & Value & Impact & Si. & Sig. & Value & Impact \\
\hline $\begin{array}{l}\text { 1.No. of } \\
\text { family } \\
\text { Members in } \\
\text { Household } \\
\end{array}$ & + & HS & .051 & Larger the family, higher the expenses & + & HS & .059 & Larger the family, higher the expenses \\
\hline $\begin{array}{l}\text { 2.Gender of } \\
\text { Household } \\
\text { Head (M/F) } \\
\end{array}$ & + & $\mathrm{S}$ & .140 & $\begin{array}{l}\text { Male were making more expenditures } \\
\text { as compared to females. }\end{array}$ & + & $\mathrm{S}$ & .289 & $\begin{array}{l}\text { Male were making more expenditures } \\
\text { as compared to females. }\end{array}$ \\
\hline $\begin{array}{c}\text { 3.Work } \\
\text { Status of } \\
\text { Household } \\
\text { Head } \\
\text { (Employed or } \\
\text { Not) } \\
\end{array}$ & + & HS & .744 & $\begin{array}{l}\text { Employed as compared to un-employed } \\
\text { incur higher expenditures. }\end{array}$ & + & HS & .753 & $\begin{array}{l}\text { Employed as compared to un-employed } \\
\text { incur higher expenditures. }\end{array}$ \\
\hline $\begin{array}{c}\text { 4.Education } \\
\text { of Household } \\
\text { Head } \\
\text { (Literate/ } \\
\text { Illiterate) }\end{array}$ & + & NS & .068 & No impact on household expenditures. & + & NS & .076 & No impact on household expenditures. \\
\hline $\begin{array}{l}\text { 5.Land } \\
\text { Ownership } \\
\text { (Having or } \\
\text { Not Having } \\
\text { Land) } \\
\end{array}$ & - & NS & -.046 & $\begin{array}{l}\text { HH having no land had no impact on } \\
\text { household expenditures. }\end{array}$ & - & NS & -.036 & $\begin{array}{l}\text { HH having no land had no impact on } \\
\text { household expenditures. }\end{array}$ \\
\hline $\begin{array}{l}\text { 6.Presence of } \\
\text { disabled } \\
\text { Persons or } \\
\text { otherwise }\end{array}$ & + & HS & .247 & $\begin{array}{l}\text { HH with disabled family members, as } \\
\text { compared to HH with no disability } \\
\text { spend more }\end{array}$ & + & HS & .251 & $\begin{array}{l}\text { HH with disabled family members, as } \\
\text { compared to HH with no disability } \\
\text { spend more }\end{array}$ \\
\hline $\begin{array}{l}\text { 7.Unexpected } \\
\text { Shocks } \\
\text { (Met/Not } \\
\text { Met) }\end{array}$ & + & NS & .035 & $\begin{array}{l}\text { Unexpected shocks had no impact on } \\
\text { household expenditures. }\end{array}$ & + & NS & .041 & $\begin{array}{l}\text { Unexpected shocks had no impact on } \\
\text { household expenditures. }\end{array}$ \\
\hline $\begin{array}{c}\text { 8.Loan } \\
\text { Obtained / } \\
\text { Not Obtained } \\
\end{array}$ & + & S & .087 & $\begin{array}{l}\mathrm{HH} \text { receiving loans compared to } \mathrm{HH} \\
\text { with no loans make higher expenditure }\end{array}$ & + & $\mathrm{S}$ & .148 & $\begin{array}{l}\mathrm{HH} \text { receiving loans compared to } \mathrm{HH} \\
\text { with no loans make higher expenditure }\end{array}$ \\
\hline $\begin{array}{c}\text { 9.Small } \\
\text { Animal } \\
\text { Owned/Not } \\
\text { Owned } \\
\end{array}$ & + & NS & .005 & $\begin{array}{l}\text { Having small animals (goats, sheep) } \\
\text { had no impact on household } \\
\text { expenditures. }\end{array}$ & + & NS & .014 & $\begin{array}{c}\text { Having small animals (goats, sheep) } \\
\text { had no impact on household } \\
\text { expenditures. }\end{array}$ \\
\hline $\begin{array}{l}\text { 10.Large } \\
\text { Animals } \\
\text { Owned/Not } \\
\text { Owned } \\
\end{array}$ & + & $\mathrm{S}$ & .124 & $\begin{array}{c}\text { Having large animals (cow, buffalo) } \\
\text { were making more expenditures as } \\
\text { compared to those who had no large } \\
\text { animal. }\end{array}$ & + & $\mathrm{S}$ & .127 & $\begin{array}{c}\text { Having large animals (cow, buffalo) } \\
\text { were making more expenditures as } \\
\text { compared to those who had no large } \\
\text { animal. }\end{array}$ \\
\hline
\end{tabular}

Abbreviations Used: Si. = Sign; Sig. = Significant; HS = Highly Significant; NS = Non-significant; HH = Household; HHH = Household Head

\section{Conclusions and Policy Recommendations}

The descriptive statistics' results, Chow's test applied and regression analysis carried out on certain vital variables showed that there was a structural break in the life of BISP beneficiaries after the program was started and their expenditure and thus consumption had also increased. Improvement in consumption pattern would mean progress in the welfare of the people and this improved welfare of the people would mean poverty was reducing.

The findings also suggest that although cash transfer of PKR. 1000 per month cannot change the whole social status of the people in this era amidst rising inflation and frequently increasing oil prices yet it provides some relief for daily household expenditures (especially food, education and health expenditures) for the poorest of the poor families. In the selected research study area, almost $91.1 \%$ of the households' heads were unemployed; they had no proper source of earning and were living from hand to mouth. For households with such a miserable social status, quarterly amount of PKR 3000 provides a reasonable relief to them at least for meeting their daily household expenditures and immediate education and health related expenditures.

The following policy recommendations stem out of the above cited conclusions, results and discussion:

1. It is a good program for the poor. This should continue whosoever is in the government but with certain modifications, especially from the standpoint of sustainability. Graduation Policy of the BISP needs to be clearly laid down and implemented gradually. There are certain initiatives already underway like Waseela-e-Haq (small loans), Waseela-e-Rozgar (technical and professional training), Waseela-e-Sehat (Life insurance up-to PKR 100,000), and Waseela-eTaleem (education of beneficiaries' children) but they need to be studied carefully before taking them to scale.

2. The Government of Pakistan and similarly, Governments of the provinces, may create a fund for this purpose. This Fund should get finances from the government, private charitable organizations and private people, foreign donors etc. Donations are possible if donors are more than hundred percent sure that their donations would be spent for the purposes 
they are intended. This Fund may generate additional funds by investments etc.

3. There should be aid for education on the basis of coresponsibility i.e. government and the beneficiary sharing the cost of education. This means careful expansion of the Waseela-e-Taleem program.

4. Time and expenditures on travel of beneficiaries should be curtailed as far as possible and to the bear minimum. A campaign to encourage people to save (even if it is a rupee a day) should be launched as part of the program.

\section{References}

[1] BISP (2011) Benazir Income Support Programme. Concept Paper. Islamabad: BISP Secretariat, Pakistan.

[2] Booysen,F (2004)Social Grants as Safety Net for HIV/AIDS affected households in South Africa. Journal of Social Aspects of HIV/AIDS Research Alliance, 1(1).

[3] Case, A and Deaton, A (1992) Large Cash Transfers to the Elderly in South Africa. NBER WORKING PAPER SERIES, Working Paper 5572.

[4] Devereux, S (2002) Can Social Safety Nets Reduce Chronic Poverty? Development Policy Review, 20(5): 657-675.

[5] Duflo (2003) Grandmothers and Grand-daughters: Old-Age Pensions and Intrahousehold Allocation in South Africa. The World Bank Economic Review, 17(1): 1-25.

[6] Hicks, N. and Q. Wodon. (2000) Economic Shocks, Safety Nets, and Fiscal Constraints: Social Protection for the Poor in Latin America, Policy Research Working Paper 5865.
[7] Imai, K (2003) The Employment Guarantee Scheme as a Social safety Net-Poverty Dynamics and Poverty Alleviation. DISCUSSION PAPER SERIES.

[8] Irfan,M. (2003) Poverty and Social Safety Nets: A Case Study of Pakistan. Islamabad: Pakistan Institute of Development Economics. (MIMAP TECHNICAL PAPER SERIES NO.15).

[9] Jalan, J and Ravallion, M (2003) Estimating the Benefit Incidence of an Antipoverty Program by Propensity-Score Matching. Journal of Business \& Economic Statistics, 2(1).

[10] Khokhar, M.D, History of Mankera State, Malik Dost Muhammad Khokhar Publishers, Bhakkar, 1988.

[11] Miankhail, S (2009) Causes and Consequences of Poverty in Pakistan. Journal of Managerial Sciences, 2(1).

[12] Ministry of Finance (2012) Economic Survey 2011-12. Islamabad: Government of Pakistan.

[13] Maluccio, J and Flores, R (2004) Impact Evaluation of Conditional Cash Transfer Program: The Nicaraguan Red De Proteccion Social. FCND DISCUSSION PAPER NO.184.

[14] Nayyab,D. and Farooq,S.(2012)Effectiveness of Cash Transfer Programmes for Household Welfare in Pakistan: The Case of the Benazir Income Support Programme. Islamabd: Pakistan Institute of Development Economics (Poverty and Social Dynamics Paper Series PSDPS: 4).

[15] Nino, C and Dorosh, P (2002) In-Kind Transfers and Household Food Consumption: Implications for Targeted Food Programs in Bangladesh. FCND DISCUSSION PAPER NO. 134.

[16] Ravallion, M et al (1994) Testing a social safety net. Journal of Public Economics, 57(1995), 175-199.

[17] Schultz, T (2001) School Subsidies for the Poor: Evaluating the Mexican Progresa Poverty Program. CENTER DISCUSSION PAPER NO.834.

[18] Wale (2003) Testing Vietnam's Public Safety Net. Social Protection Discussion Paper Series No. 0319. 